\title{
Pengaruh Penambahan Enzim Bromelin pada Pakan terhadap Kecernaan Protein, Efisiensi Pemanfaatan Pakan dan Pertumbuhan Udang Windu Penaeus monodon, Fabricius 1798 (Malacostraca: Penaeidae)
}

\author{
Diana Rachmawati 1*, Johannes Hutabarat', Eko Nurcahya Dewi ${ }^{2}$, dan \\ Seto Windarto ${ }^{1}$
'Departemen Akuakultur, Fakultas Perikanan dan Ilmu Kelautan, Universitas Diponegoro 2Departemen Teknologi Hasil Perikanan, Fakultas Perikanan dan Ilmu Kelautan, Universitas Diponegoro
JI. Prof. Soedarto SH, Tembalang, Semarang, Jawa Tengah 50275 Indonesia
Email: dianarachmawati1964@gmail.com

\begin{abstract}
The Effect of Bromelains Addition in Feed to Protein Digestibility, Feed Utilization Efficiency, and Growth of Penaeus Monodon Fabricius
\end{abstract}

Feed utilization efficiency is one of the problems that often faced by tiger shrimp (Penaeus monodon Fabricus) farmers, which is $40-60 \%$ of production costs used for feed. The efficiency of feed can be improved by the addition of the bromelains in the feed, which can hydrolyze proteins into simpler compounds to increase the digestibility of the feed protein. This study aims to examine the effect of bromelains in feed on protein digestibility (ADCP), feed utilization efficiency (EPP), and growth (RGR) of tiger shrimp. Tiger shrimp with an average weight of $2.8 \pm$ $0.26 \mathrm{~g} /$ individual was obtained from the Brackish Water Aquaculture Development Centre (BBPBAP), Jepara. There were 6 treatments adding bromelains in the feed, A (0\%), B (0.2\%), C (0.4\%), D (0.6\%) and E (0.8\%). Observation parameters, including ADCP, EPP, PER, RGR, SR, and water quality parameters. The results showed that the addition of the bromelains in feed increased ADCP, EPP, PER, RGR, but had no effect on the SR of tiger shrimp. Bromelains $10.4 \%$ / $\mathrm{kg}$ ) of feed is the optimal dose of ADCP, EPP, and RGR, resulting in a maximum value of $82.59 \%$, $88.17 \%$, and $5.24 \%$ / day.

Keywords: Penaeus monodon; digestibility; protein; feed; bromelains

\begin{abstract}
Abstrak
Permasalahan yang sering dihadapi pembudidaya udang windu (Penaeus monodon Fabricius) adalah efisiensi pemanfaatan pakan yang belum maksimal sehingga hampir $40-60 \%$ dari total biaya produksi untuk biaya pakan. Efisiensi pemanfaatan pakan dapat ditingkatkan dengan penambahan enzim bromelin dalam pakan yang mampu menghidrolisis protein menjadi senyawa yang lebih sederhana sehingga dapat meningkatkan daya cerna protein pakan. Penelitian ini bertujuan mengkaji pengaruh enzim bromelin dalam pakan terhadap kecernaan protein (ADCP), efisiensi pemanfaatan pakan (EPP) dan pertumbuhan (RGR) udang windu. Hewan uji berupa udang windu dengan bobot rata-rata 2,8 $\pm 0,26 \mathrm{~g} / \mathrm{ekor}$ diperoleh dari Balai Besar Perikanan Budidaya Air Payau (BBPBAP), Jepara sebagai tempat penelitian. Terdapat 6 perlakuan penambahan enzim bromelin dalam pakan yaitu A $(0 \%), B(0,2 \%), C(0,4$ $\%)$, D $(0,6 \%)$ dan E (0,8 \%). Pengamatan parameter meliputi ADCp, EPP, PER, RGR, SR dan parameter kualitas air. Hasil penelitian menunjukkan bahwa penambahan enzim bromelin dalam pakan meningkatkan ADCp, EPP, PER, RGR, namun tidak berpengaruh pada SR udang
\end{abstract}


windu. Enzim bromelin 0,4\%/kg pakan merupakan dosis optimal pada ADCp, EPP dan RGR menghasilkan nilai maksimal sebesar $82,59 \%, 88,17 \%$ dan $5,24 \%$ /hari.

Kata kunci: Penaeus monodon; kecernaan; protein; pakan; enzim bromelin

\section{PENDAHULUAN}

Udang windu (Penaeus monodon, Fabricus) adalah spesies endogen Indonesia. Peningkatan produksi udang windu berbanding lurus dengan kebutuhan pakan (Rachmawati et al., 2016). Masalah yang sering dihadapi pembudidaya udang windu adalah efisiensi pemanfaatan pakan yang belum maksimal sehingga $40-60 \%$ dari total biaya produksi hanya untuk biaya pakan (Hugues et al., 2018). Peningkatan efisiensi pemanfaatan pakan dapat dengan penambahan enzim eksogenus yang ditambahkan dalam pakan ikan (Manush et al., 2013). Salah satu enzim eksogenus adalah enzim bromelin dalam ekstrak nanas (Choi et al., 2016).

Enzim bromelin dalam ekstrak nanas secara khusus memotong ikatan peptida pada ujung karbonil lisin, alanin, tirosin dan glisin (Hardiany, 2013). Bromelin diakui oleh Agensi Federal Amerika Serikat umumnya dikenal sebagai GRAS untuk meningkatkan keempukan daging (Nadzirah et al., 2016). Satuan berat molekul enzim protease buah nanas adalah $30,654 \mathrm{kDa}$ (Rachmania et al., 2017) dan aktivitas enzim bromelin dari nanas adalah $0,15 \mathrm{U} / \mathrm{ml}$ (Omotoyinbo dan Sanni, 2017). Enzim bromelin diperoleh dari ekstrak nanas merupakan salah satu enzim proteolitik yang mampu menghidrolisis protein menjadi senyawa yang lebih sederhana dan memutus ikatan peptida dari ikatan substrat yang berperan sebagai katalisator dalam sel sehingga dapat meningkatkan daya cerna protein pakan (Mohan et al., 2016).

Penelitian penambahan ekstrak nanas dalam pakan pada beberapa spesies ikan dilaporkan oleh Inaolaji, (2011) menyatakan ikan nila (Oreochromis niloticus) yang diberi pakan dengan penambahan ekstrak nanas sebanyak $75 \% / \mathrm{kg}$ pakan memiliki laju pertumbuhan relatif terbaik, Masniar et al. (2016) melaporkan ikan betok (Anabas testudineus) memiliki pertumbuhan terbaik setelah diberi pakan dengan dengan penambahan ekstrak nanas sebesar $5 \% / \mathrm{kg}$ pakan, Subandiyono et al. (2018) mengemukakan ikan java barb (Pintius javanicus) memiliki efisiensi pemanfaatan pakan sebesar $67,29 \%$, rasio efisiensi protein sebesar 1,10\%, dan laju pertumbuhan relatif sebesar 1,94\%/hari setelah diberi pakan dengan dosis optimum ekstrak nanas 1,852,13\%, Yuangsoi et al. (2018) menjelaskan pertumbuhan dan efisiensi pemanfaatan pakan yang optimum ikan nila (Oreochromis niloticus) diperoleh setelah diberi pakan dengan penambahan ekstrak nanas sebesar $1 \% / \mathrm{kg}$ pakan, Rachmawati dan Samidjan (2018) mengutarakan ekstrak nanas sebesar $0,2 \mathrm{ml} / \mathrm{kg}$ pakan menjadikan udang vaname (Litopenaues vannamei) memiliki efisiensi pemanfaatan pakan dan pertumbuhan terbaik. Dari uraian tersebut di atas dapat disimpulkan bahwa kebutuhan ekstrak nanas pada setiap spesies ikan berbeda. Informasi penelitian penambahan ekstrak enzim dalam pakan untuk udang windu belum banyak ditemukan, maka pentingnya penelitian ini dilakukan untuk meningkatkan efisiensi pemanfaatan pakan. Tujuan penelitian ini adalah mengkaji pengaruh penambahan enzim bromelin dalam pakan terhadap kecernaan protein, efisiensi pemanfaatan pakan dan pertumbuhan udang windu ( $P$. monodon Fabricius).

\section{MATERI DAN METODE}

Penelitian ini dilaksanakan di Laboratorium Pakan Buatan Balai Besar Perikanan Budidaya Air Payau (BBPBAP), Jepara pada bulan April s/d Juli 2019. Hewan uji berupa udang windu yang diperoleh dari pembenihan di BBPBAP, Jepara dengan bobot rata-rata 2,8 $\pm 0,26$ g/ekor. Sebelum pelaksanaan penelitian dilakukan adaptasi udang terhadap pakan dan lingkungan selama satu minggu. Selama adaptasi udang diberi pakan buatan komersial tanpa penambahan enzim bromelin dan pakan diberikan sampai udang kenyang. Satu hari 
sebelum pelaksanaan penelitian udang dipuasakan untuk menghilangkan sisa metabolisme dalam tubuh udang. Sebagai hewan uji dalam penelitian, udang dipilih yang memiliki ukuran seragam, sehat, tidak cacat dan aktif berenang (Rachmawati et al., 2017). Pemberian pakan selama penelitian dilakukan dengan menggunakan metode fix feeding rate sebanyak 5\%/bobot biomassa/hari dan frekuensi pakan yang diberikan sebanyak 4 kali sehari, pada pukul 08.00, 14.00,18.00, 21.00 .

Metode penelitian yang digunakan adalah rancangan acak lengkap (RAL), 5 perlakuan dan 4 kali pengulangan. Perlakuan dalam penelitian ini adalah penambahan ekstrak nanas dalam pakan dengan dosis berbeda. Pakan uji yang digunakan dalam penelitian ini merupakan pakan buatan kandungan protein $40 \%$ ditambah enzim bromelin sesuai perlakuan $\mathrm{A}$ (0\%/kg pakan), B $(0,2 \% / \mathrm{kg}$ pakan), C $(0,4$ $\% / \mathrm{kg}$ pakan), D $(0,6 \% / \mathrm{kg}$ pakan) dan $\mathrm{E}(0,8$ $\% / \mathrm{kg}$ pakan). Penentuan dosis ekstrak nanas dalam penelitian ini memodifikasi hasil penelitian Rachmawati dan Samidjan (2018) yang melaporkan bahwa ekstrak nanas dosis $0,2 \% / \mathrm{kg}$ pakan memberikan efisiensi pemanfaatan pakan dan pertumbuhan terbaik untuk udang vaname (L. vannamei). Pembuatan ekstraksi nanas untuk menghasilkan enzim bromelin mengacu pada metode Masniar et al., (2016) yang dilakukan di Laboratorium Biologi Universitas Negeri Semarang. Bahan baku penyusun pakan uji terdiri dari tepung ikan sebagai sumber protein hewani, tepung kedelai sebagai sumber protein nabati, tepung jagung, tepung dedak dan tepung terigu sebagai sumber karbohidrat, minyak ikan dan minyak jagung sebagai sumber lemak, mineral dan vitamin mix sebagai sumber mineral dan vitamin, CMC sebagai binder, ekstrak nanas dan $\mathrm{Cr}_{2} \mathrm{O}_{3} \quad 0,5 \%$ sebagai indikator kecernaan protein (NRC, 2011). Formulasi dan hasil analisa proksimat pakan uji (Tabel 1).

Wadah penelitian yang digunakan dalam penelitian ini adalah bak fiber ukuran $1 \times 1 \times 1 \mathrm{~m}^{3}$ berjumlah 20 bak fiber yang masingmasing dilengkapi dengan sistem resirkulasi. Penempatan wadah penelitian dilakukan secara acak dengan air media budidaya memiliki salinitas 25 ppt (Syukri dan Ilham, 2016). Masing-masing bak fiber diisi udang windu dengan padat penebaran 1 ekor/liter. Pengamatan parameter kualitas air selama penelitian meliputi salinitas, $\mathrm{pH}, \mathrm{DO}$, amonia dan nitrit. Pemeliharaan kualitas air dilakukan dengan cara penyiponan feses dan sisa pakan 2 kali dalam satu hari yaitu pada pagi hari dan sore hari. Penyiponan dilakukan untuk membersihkan media budidaya agar tetap bersih dan layak untuk kehidupan udang windu. Parameter yang diamati meliputi kecernaan protein (ADCP), efisiensi pemanfaatan pakan (EPP), rasio efisiensi protein (PER), laju pertumbuhan relatif (RGR), kelulushidupan (SR) dan parameter kualitas air.

\section{Kecernaan Protein (ADCp)}

Perhitungan nilai kecernaan protein (ADCP) dihitung dengan menggunakan rumus Fenucci (1981) sebagai berikut :

$$
A D C p=100-\left\{100 \times \frac{\left(a \times b^{\prime}\right)}{\left(a^{\prime} \times b\right)}\right\}
$$

Keterangan : $A D C P=$ Kecernaan protein

$a=\% \mathrm{Cr}_{2} \mathrm{O}_{3}$ pakan; $a^{\prime}=\% \mathrm{Cr}_{2} \mathrm{O}_{3}$ feses; $b=\%$ protein pakan; $b^{\prime}=\%$ protein feses

\section{Efisiensi pemanfaatan pakan (EPP)}

Perhitungan nilai efisiensi pemanfaatan pakan (EPP) dihitung dengan menggunakan rumus NRC (2011) sebagai berikut :

$$
\mathrm{EPP}=\frac{\mathrm{W} t-\mathrm{WO}_{0}}{\mathrm{~F}} \times 100 \%
$$

Keterangan : $\mathrm{EPP}=$ Efisiensi pemanfaatan pakan (\%); $\mathrm{W} t=$ Bobot total ikan uji pada akhir penelitian (g); Wo = Bobot total ikan uji pada awal penelitian (g); $F=$ Jumlah pakan yang dikonsumsi selama penelitian (g)

\section{Rasioefisiensi protein (PER)}

Perhitungan nilai rasio efisiensi protein dengan menggunakan rumus NRC (2011) sebagai berikut:

PER $=\frac{W_{+}-W_{\circ}}{\mathrm{Pi}} \times 100 \%$

Keterangan : PER = Rasio efisiensi protein (\%); $\mathrm{W}_{+}=$Bobot total ikan uji pada akhir penelitian (g); $W_{\circ}=$ Bobot total ikan uji pada awal penelitian (g); $\mathrm{Pi}=$ Berat pakan yang dikonsumsi $x \%$ protein pakan 
Tabel 1. Formulasi dan hasil analisis proksimat pakan uji

\begin{tabular}{lrrrrr}
\hline \multirow{2}{*}{ Bahan Baku Penyusun Pakan } & \multicolumn{3}{c}{ Perlakuan } \\
\cline { 2 - 6 } & $\mathrm{A}$ & $\mathrm{B}$ & $\mathrm{C}$ & $\mathrm{D}$ & $\mathrm{E}$ \\
\hline Ekstrak nanas & 0 & 0,20 & 0,40 & 0,60 & 0,80 \\
Tepung ikan & 28,00 & 28,00 & 28,00 & 28,00 & 28,00 \\
Tepung kedelai & 37,80 & 37,80 & 37,80 & 37,80 & 37,80 \\
Tepung jagung & 6,50 & 6,50 & 6,50 & 6,50 & 6,50 \\
Tepung dedak & 8,21 & 8,21 & 8,21 & 8,21 & 8,21 \\
Tepung Terigu & 11,99 & 11,79 & 11,59 & 11,39 & 11,19 \\
Minyak ikan & 3,00 & 3,00 & 3,00 & 3,00 & 3,00 \\
Minyak jagung & 2,00 & 2,00 & 2,00 & 2,00 & 2,00 \\
Vit Min Mix & 1,00 & 1,00 & 1,00 & 1,00 & 1,00 \\
CMC & 1,00 & 1,00 & 1,00 & 1,00 & 1,00 \\
Crin & 0,50 & 0,50 & 0,50 & 0,50 & 0,50 \\
\hline Total (g) & 100 & 100 & 100 & 100 & 100 \\
\hline Hasil analisa proksimat & & & & & \\
Protein (\%)* & 40,12 & 40,12 & 40,13 & 40,11 & 40,10 \\
Lemak (\%)* & 10,76 & 10,64 & 10,66 & 10,53 & 10,53 \\
BETN (\%)* & 34,34 & 34,34 & 34,40 & 34,50 & 34,50 \\
Energi (kkal) & 325,73 & 325,27 & 325,94 & 325,79 & 325,61 \\
Rasio E/P & 8,11 & 8,10 & 8,12 & 8,12 & 8,11 \\
\hline Keterangan: & & & & &
\end{tabular}

Keterangan:

a. Dihitung berdasarkan pada Digestible Energy menurut Wilson (1982) untuk $1 \mathrm{~g}$ protein adalah 3,5

$\mathrm{kkal} / \mathrm{g}, 1 \mathrm{~g}$ lemak adalah $8,1 \mathrm{kkal} / \mathrm{g}$, dan $1 \mathrm{~g}$ karbohidrat adalah 2,5 kkal/g.

b. Menurut NRC (2011), nilai E/P bagi pertumbuhan optimal ikan berkisar antara 8-12 kkal/g.

c. *Laboratorium Ilmu Makanan Ternak, Fakultas Peternakan dan Pertanian, Universitas Diponegoro (2019)

\section{Laju pertumbuhan relatif ( $R G R)$}

Menurut NRC (2011), laju pertumbuhan relatif (RGR) ikan dihitung dengan menggunakan rumus:

$$
R G R=\frac{W_{t}-W_{0}}{W_{0} \times \dagger} \times 100 \%
$$

Keterangan : $R G R=$ Laju pertumbuhan relatif (\% per hari); $W_{t}=$ Bobot total ikan uji pada akhir pemeliharaan $(\mathrm{g}) ; W_{\circ}=$ Bobot total ikan uji pada awal pemeliharaan (g); $\dagger=$ Waktu pemeliharaan (hari)

\section{Kelulushidupan (SR)}

Menurut Effendi (1997), bahwa kelulushidupan merupakan prosentase kelulushidupan ikan yang dapat dihitung dengan rumus sebagai berikut:

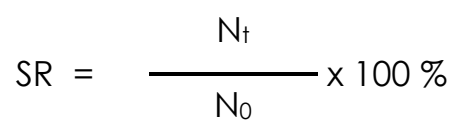

Keterangan: $S R$ = Tingkat kelulushidupan ikan (\%); $N_{t}=$ Jumlah ikan pada akhir penelitian (ekor); $\mathrm{N}_{0}=$ Jumlah ikan pada awal penelitian (ekor)
Data pengamatan parameter yang telah diperoleh dianalisis menggunakan analisis ragam (ANOVA) pada taraf kepercayaan $95 \%$ dan $99 \%$ untuk melihat pengaruh perlakuan. Apabila dalam analisis ragam diperoleh berpengaruh nyata $(P<0,05)$ atau berpengaruh sangat nyata $(P<0,01)$, maka dilakukan uji wilayah ganda duncan untuk mengetahui perbedaan antar perlakuan. Dosis ekstrak nanas optimal pada pakan dilakukan analisis polinomial ortogonal dengan software Maple 2016 (Stell et al., 1997).

\section{HASIL DAN PEMBAHASAN}

Data kecernaan protein (ADCP), efisiensi pemanfaatan pakan (EPP), protein efisiensi rasio (PER), laju pertumbuhan relative (RGR) dan kelulushidupan (SR) dan parameter kualitas udang windu selama penelitian disajikan pada Tabel 2 dan 3.

Hasil analisis ragam menunjukkan bahwa penambahan enzim bromelin dalam 
pakan berpengaruh sangat nyata $(P<0,01)$ terhadap ADCP udang windu. Mo et al. (2016) melaporkan penambahan enzim proteolitik dapat meningkatkan pencernaan bahan penyusun pakan khususnya yang mengandung protein nabati. Enzim bromelin dalam ekstrak nanas berguna untuk membantu ikan jenis karnivora dalam mencerna pakan yang banyak mengandung bahan nabati sehingga dapat meningkatkan kecernaan protein pakan (Mohan et al., 2016). Selanjutnya Choi et al. (2012) menyatakan bahwa enzim bromelin dalam ekstrak nanas merupakan enzim proteolitik yang berperan sebagai enzim pencernaan terutama pencernaan protein. Protein yang terkandung dalam pakan mampu dihidrolisis oleh enzim bromelin menjadi asam amino, sehingga protein dalam pakan menjadi lebih mudah dicerna udang windu. Udang windu yang diberi pakan $C(0,4 \% / \mathrm{kg}$ pakan) memiliki nilai ADCp tertinggi sebesar $82,59 \%$ diikuti pakan D $(0,6 \% / \mathrm{kg}$ pakan) sebesar $75,16 \%$, pakan B $(0,2 \% / \mathrm{kg}$ pakan) sebesar $67,32 \%$, pakan $\mathrm{E}(0,8 \% / \mathrm{kg}$ pakan) sebesar $60,52 \%$ dan pakan A (0 \%/kg pakan) sebesar 55,27\%. Tingginya nilai ADCp udang windu yang diberi pakan $C(0,4 \% / \mathrm{kg}$ pakan) diduga pada dosis tersebut merupakan dosis efektif enzim bromelin alam ekstrak dalam pencernaan protein udang windu.

Peningkatan dosis enzim bromelin melebihi dosis maksimal belum tentu memberikan hasil nilai ADCp yang tinggi. Dalam penelitian ini dapat dilihat penurunan nilai ADCp pada udang windu yang diberi pakan dengan penambahan enzim bromelin lebih tinggi dari $0,4 \% / \mathrm{kg}$ pakan (C). Hal itu berkaitan dengan mekanisme kerja dari enzim bromelin yang terkandung dalam ekstrak nanas seperti yang dijelaskan oleh

Tabel 2. Data kecernaan protein (ADCP), efisiensi pemanfaatan pakan (EPP), protein efisiensi rasio (PER), laju pertumbuhan relatif (RGR) dan kelulushidupan (SR) udang windu selama penelitian.

\begin{tabular}{cccccc}
\hline \multirow{2}{*}{ Perlakuan } & \multicolumn{5}{c}{ Parameter yang diamati } \\
\cline { 2 - 6 } & ADCp (\%) & EPP (\%) & PER (\%) & RGR(\%/hari) & SRc(\%) \\
\hline A & $55,27 \pm 0,53 \mathrm{e}$ & $60,35 \pm 0,36 \mathrm{e}$ & $1,58 \pm 0,42^{\mathrm{e}}$ & $2,27 \pm 0,42^{\mathrm{e}}$ & $83,35 \pm 2,33 \mathrm{e}$ \\
B & $67,32 \pm 0,84^{\mathrm{c}}$ & $73,42 \pm 0,45^{\mathrm{c}}$ & $1,89 \pm 0,36^{\mathrm{c}}$ & $3,47 \pm 0,29 \mathrm{c}$ & $93,33 \pm 1,33^{\mathrm{c}}$ \\
C & $82,59 \pm 0,49 \mathrm{a}$ & $88,17 \pm 0,63^{\mathrm{a}}$ & $3,72 \pm 0,27 \mathrm{a}$ & $5,24 \pm 0,28^{\mathrm{a}}$ & $93,33 \pm 1,33^{\mathrm{a}}$ \\
D & $75,16 \pm 0,27 \mathrm{~b}$ & $80,35 \pm 0,52^{\mathrm{b}}$ & $2,24 \pm 0,36^{\mathrm{b}}$ & $4,18 \pm 0,43^{\mathrm{b}}$ & $93,33 \pm 1,33^{\mathrm{b}}$ \\
E & $60,52 \pm 0,56^{\mathrm{d}}$ & $68,24 \pm 0,73^{\mathrm{d}}$ & $1,62 \pm 0,73^{\mathrm{d}}$ & $3,02 \pm 0,15^{\mathrm{d}}$ & $93,33 \pm 1,33^{\mathrm{d}}$ \\
\hline
\end{tabular}

Keterangan: Nilai rerata dengan huruf superscript yang berbeda menunjukkan adanya perbedaan yang nyata $(P<0,05)$

Tabel 3. Parameter kualitas air media budidaya udang windu selama penelitian

\begin{tabular}{cccccc}
\hline \multirow{2}{*}{ Perlakuan } & \multicolumn{5}{c}{ Kisaran Nilai Parameter Kualitas Air } \\
\cline { 2 - 6 } & Suhu $\left({ }^{\circ} \mathrm{C}\right)$ & $\mathrm{pH}$ & $\mathrm{DO}(\mathrm{mg} / \mathrm{l})$ & $\mathrm{NH}_{3}(\mathrm{mg} / \mathrm{l})$ & Salinitas $(\mathrm{ppt})$ \\
\hline $\mathrm{A}$ & $26-29$ & $7,3-7,6$ & $5,6-6,0$ & $0,001-0,039$ & $25^{\mathrm{c}}$ \\
$\mathrm{B}$ & $26-29$ & $7,4-7,5$ & $5,3-6,0$ & $0,001-0,039$ & $25^{\mathrm{c}}$ \\
$\mathrm{C}$ & $26-29$ & $7,4-7,6$ & $5,4-6,0$ & $0,001-0,039$ & $25^{\mathrm{c}}$ \\
D & $26-29$ & $7,3-7,6$ & $5,4-6,0$ & $0,001-0,039$ & $25^{\mathrm{c}}$ \\
E & $26-29$ & $7,3-7,5$ & $5,3-6,0$ & $0,001-0,039$ & $25^{\mathrm{c}}$ \\
Nilai Kelayakan & $28-32^{\mathrm{a}}$ & $6,5-8,5 \mathrm{a}$ & $\geq 3 \mathrm{a}$ & $<0,20 \mathrm{~b}$ & $25^{\mathrm{b}}$ \\
\hline
\end{tabular}

Keterangan: a)Tricahyo, (1994); b)Boyd, (2003); c)Syukri dan Ilham, (2016) 
Khattak et al. (2006) bahwa enzim mengkatalis secara spesifik dan bertindak pada satu substrat. Pernyataan tersebut dapat disimpulkan ketika tidak tersedia substrat untuk enzim, maka tidak ada aktivitas enzim. Hal ini terjadi pada perlakuan yang penambahan enzim bromelin dalam ekstrak nanas berlebihan namun substratnya terbatas. Penambahan enzim secara berlebihan dengan substrat terbatas tidak dapat meningkatkan aktivitas enzim, karena aktivitas enzim terhenti saat substrat habis. Lebih lanjut Adugna et al. (2004) menjelaskan meningkatkan konsentrasi subtrat dapat meningkatkan aktivitas enzim sampai batas maksimum tercapai. Kondisi tersebut menunjukkan bahwa molekul substrat dan molekul enzim akan bergabung pada sisi aktif sampai semua sisi aktif terpakai, pada keadaan tersebut enzim dikatakan dalam keadaan maksimum. Hasil uji Polinomial Orthogonal hubungan antara penambahan enzim bromelin dalam pakan dengan ADCp berpola kuadratik $Y=-135,86 X^{2}+117,86 x+$ 53,635, $R^{2}=0,927$ (Gambar 1). Dari persamaan tersebut diperoleh dosis enzim bromelin optimal sebesar $0,4 \% / \mathrm{kg}$ pakan mampu menghasilkan ADCp maksimal sebesar $82,59 \%$.

Efisiensi pemanfaatan pakan (EPP) merupakan jumlah pakan yang mampu dimanfaatkan oleh tubuh untuk tumbuh ikan
(Rachmawati et al., 2019). Udang windu yang diberi pakan dengan penambahan enzim bromelin memiliki nilai EPP lebih tinggi jika dibandingkan tanpa penambahan. Menurut Obirikorang et al. (2015), dengan penambahan ekstrak nanas yang mengandung enzim bromelin dalam pakan akan menambah profil asam amino khususnya metionin dalam pakan menjadikan efisiensi pemanfaatan pakan lebih maksimal dibandingkan tanpa penambahan. Dalam penelitian ini pakan uji dari setiap perlakuan dalam penelitian ini dapat dikatakan memiliki kualitas baik karena memiliki nilai EPP di atas 50\%. Craig dan Helfrich (2002) menyatakan pakan memiliki kualitas baik bila nilai efisiensi pemanfaatan pakan lebih dari $50 \%$ atau bahkan mendekati $100 \%$.

Udang windu yang diberi pakan dengan penambahan enzim bromelin sebesar $0,4 \% / \mathrm{kg}$ pakan (C) memiliki nilai EPP tertinggi, hal ini diduga dosis tersebut paling efektif dalam meningkatkan efektivas dari enzim bromelin dalam ekstrak nanas untuk menghidrolisis ikatan peptida pada protein atau polipeptida menjadi molekul yang lebih kecil yaitu asam amino sehingga meningkatkan efisiensi pemanfaatan pakan. Mo et al. (2016) melaporkan penambahan enzim proteolitik meningkatkan kecernaan protein pakan dan efisiensi pemanfaatan

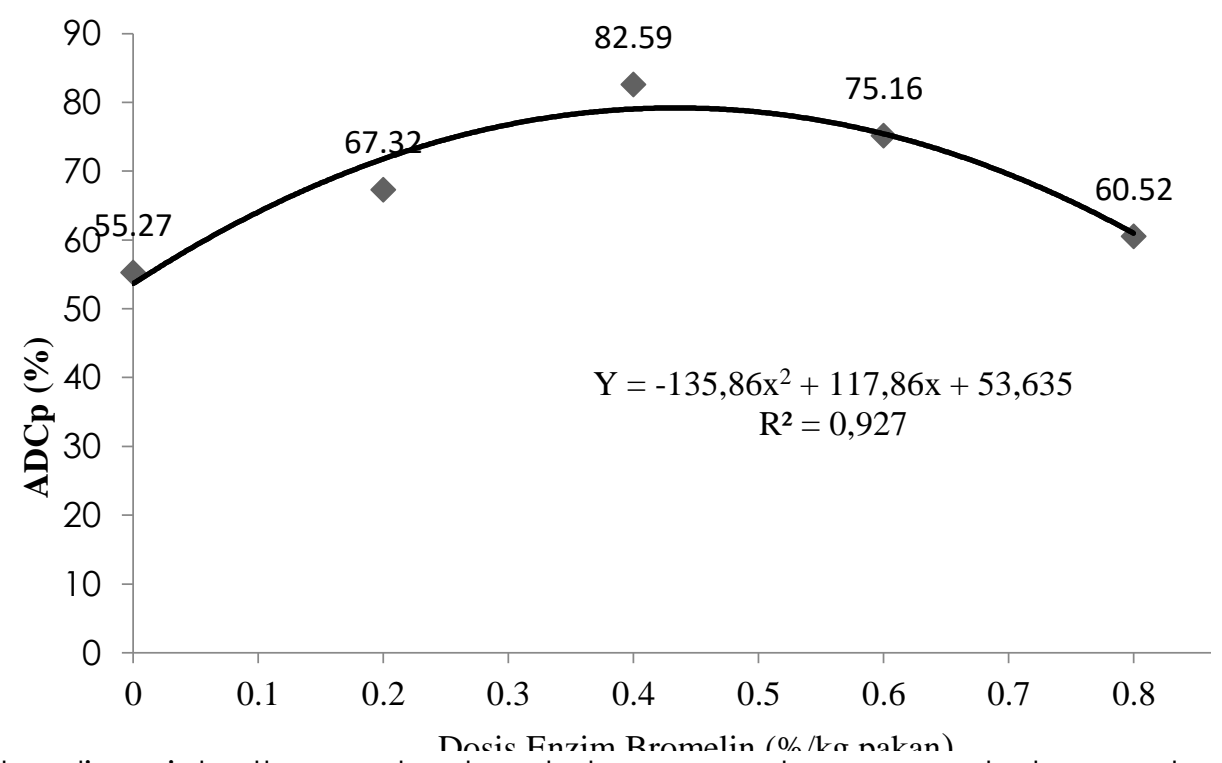

Gambar 1. Grafik polinomial orthogonal antara hubungan antara penambahan pakan enzim bromelin dalam pakan dengan ADCp udang windu selama penelitian 


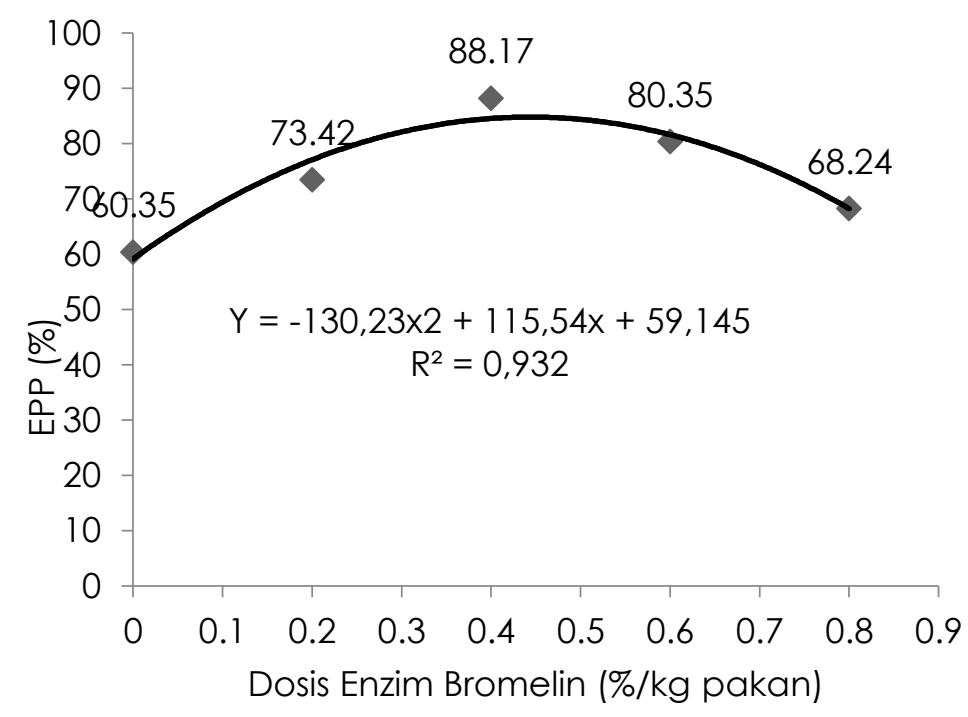

Gambar 2. Grafik polinomial orthogonal antara hubungan antara penambahan pakan enzim bromelin dalam pakan dengan EPP udang windu selama penelitian

Rasio efisiensi protein (PER) merupakan nilai yang menunjukkan jumlah bobot ikan yang dihasilkan dari tiap unit berat protein dalam pakan dengan asumsi bahwa semua protein digunakan untuk pertumbuhan (NRC, 2011). Nilai PER udang windu yang diberi pakan dengan penambahan enzim bromelin (B, C, D, E) lebih tinggi dibandingkan tanpa penambahan (A). Menurut Mohan et al. (2016), bahwa bromelin merupakan salah satu bahan alami yang mengandung enzim proteolitik yang mampu menghidrolisis protein menjadi senyawa yang lebih sederhana dan memutus ikatan peptide dari ikatan substrat yang berperan sebagai katalisator dalam sel sehingga dapat meningkatkan daya cerna protein sehingga meningkatkan pembentukan protein tubuh ikan. Nilai PER udang windu yang diperoleh dalam penelitian ini berturut-turut yaitu perlakuan $\mathrm{C}$ $(0,4 \% / \mathrm{kg}$ pakan) sebesar 3,72 , perlakuan $D$ $(0,6 \% / \mathrm{kg}$ pakan) sebesar 2,24 , perlakuan B $(0,2 \% / \mathrm{kg}$ pakan) sebesar 1,89 , perlakuan $\mathrm{E}$ (0,8\%/kg pakan) sebesar 1,62 dan perlakuan A $(0 \% / \mathrm{kg}$ pakan) sebesar 1,58 . Udang windu yang diberi pakan dengan penambahan enzim bromelin sebesar $0,4 \% / \mathrm{kg}$ pakan (C) memiliki nilai PER tertinggi diantara perlakuan lain, diduga dosis tersebut merupakan dosis yang sesuai untuk menguraikan protein pakan dapat dimanfaatkan oleh ikan untuk membentuk protein tubuh secara maksimal.
Choi et al. (2016) menyatakan bahwa penambahan enzim dalam pakan dalam jumlah tertentu akan semakin banyak jumlah protein yang dihidrolisis menjadi asam amino, dan dengan demikian meningkatkan penyerapan protein membentuk protein tubuh ikan. Hasil uji Polinomial Orthogonal hubungan antara penambahan ekstrak bromelin dalam pakan dengan PER berpola kuadratik $Y=-9,2321 X^{2}+7,6007 x+1,3854, R^{2}=$ 0,814 (Gambar 3), dari persamaan tersebut diketahui dosis enzim papain yang optimal sebesar $0,4 \% / \mathrm{kg}$ pakan mampu menghasilkan PER maksimal 3,72.

Hasil penelitian menunjukkan udang windu yang diberi pakan $C$ dengan penambahan ekstrak nanas yang mengandung enzim bromelin sebesar $0,4 \% / \mathrm{kg}$ pakan menghasilkan nilai RGR tertinggi sebesar 5,24\%/hari. Hal ini diduga dikarenakan enzim bromelin pada dosis tersebut lebih efektif menghidrolisis protein komplek menjadi asam amino lebih maksimal dibandingkan dengan perlakuan lain. Nilai RGR udang windu dalam penelitian ini berbanding lurus dengan nilai EPP, sehingga nilai EPP yang semakin tinggi akan diikuti nilai RGR yang semakin tinggi. Hal ini sesuai dengan pendapat Obirikorang et al. (2015) yang melaporkan dengan penambahan enzim bromelin dalam pakan akan 
meningkatkan efisiensi pemanfaatan pakan dan meningkatkan pertumbuhan ikan. Hasil penelitian serupa pada beberapa spesies ikan yaitu $O$. niloticus (Inaolaji, 2011), Ctenopharyngodon idella (Choi et al., 2012), Litopenaeus vannamei (Rachmawati dan Samidjan, 2018). Hasil uji Polinomial Orthogonal hubungan antara penambahan enzim bromelin dalam pakan dengan RGR berpola kuadratik $Y=-13,482 x^{2}+11,891 x+$ 2,1154, $R^{2}=0,887$ (Gambar 4), dari persamaan tersebut diketahui dosis enzim papain yang optimal sebesar $0,4 \% / \mathrm{kg}$ pakan mampu menghasilkan RGR maksimal $5,24 \%$ /hari.
Hasil analisis ragam menunjukkan bahwa penambahan enzim bromelin dalam pakan tidak berpengaruh nyata $(P>0,05)$ terhadap kelulushidupan udang windu. Hal ini menunjukkan bahwa penambahan ekstrak nanas yang mengandung enzim bromelin yang merupakan enzim proteolitik tidak berpengaruh terhadap kelulushidupan udang windu. Hasil penelitian ini sesuai dengan pendapat Dabrowski dan Glogowski (1977) yang menyatakan enzim proteolitik jika ditambahkan ke dalam pakan itu tidak berpengaruh signifikan pada tingkat kelangsungan hidup. Hasil penelitian serupa dilaporkan oleh Subandiyono et al. (2018),

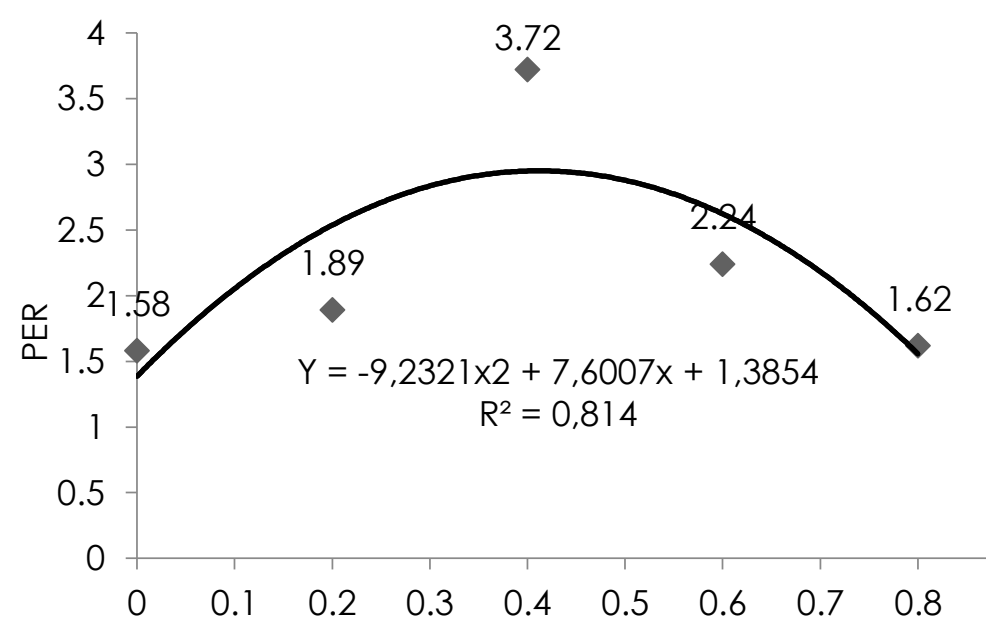

Gambar 3. Grafik polinomial orthogonal antara hubungan antara penambahan pakan enzim bromelin dalam pakan dengan PER udang windu selama penelitian

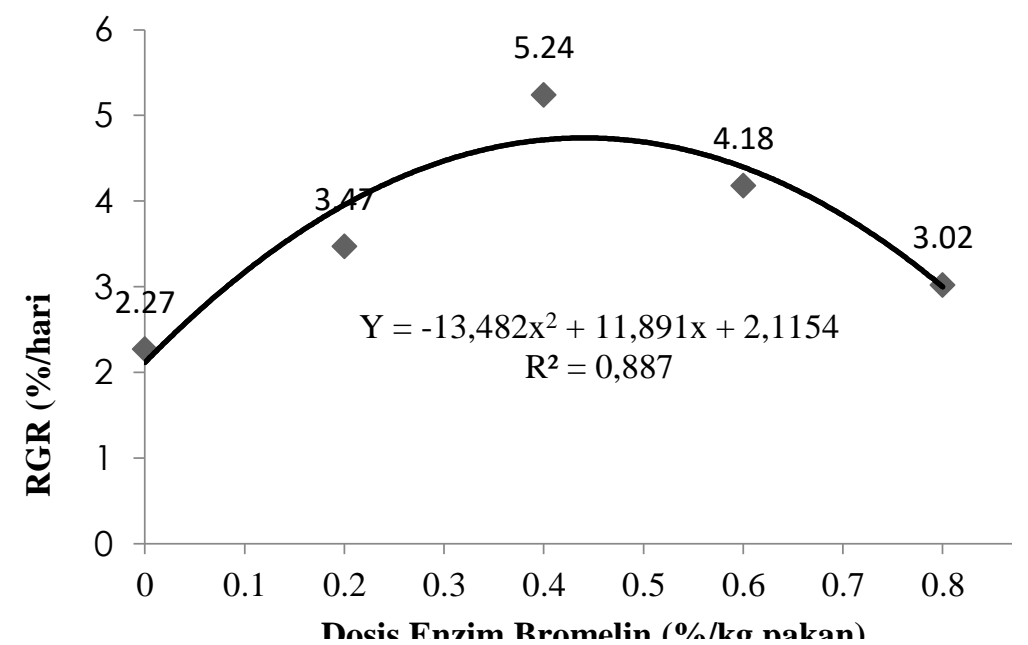

Gambar 4. Grafik polinomial orthogonal antara hubungan antara penambahan pakan enzim bromelin dalam pakan dengan RGR udang windu selama penelitian 
Lima et al. (2012), Rachmawati dan Samidjan, (2018), Inaolaji, (2011) dan Choi et al. (2012).

\section{KESIMPULAN}

Penambahan enzim bromelin dari ekstrak nanas dalam pakan buatan dapat meningkatkan kecernaan protein, efisiensi pemanfaatan pakan dan pertumbuhan udang windu. Dosis enzim bromelin sebesar $0,4 \% / \mathrm{kg}$ pakan merupakan dosis optimal yang menghasilkan nilai maksimal ADCp sebesar $82,59 \%$, EPP sebesar 88,17 dan RGR sebesar 5,24\%/hari.

\section{DAFTAR PUSTAKA}

Adugna, S., Alemu, L.A.M., Kelemu, T., Tekola, H., Kibret, B.\& Genet, S. 2004. Medical Biochemistry. Gondar University; Jimma University and Debub University, In collaboration with the Ethiopia Public Health Training Initiative; The Carter Center; The Ethiopia Ministry of Health, and The Ethiopia Ministry of Education, $264 \mathrm{p}$.

Boyd, C.E., .2003. Guidelines for aquaculture effluent management at the farm-level. Aquaculture, 226(1-4):101-112. doi: 10.1016/S0044-8486(03)00471-X.

Choi, W.M., Lam, C.L., Mo, W.Y. \& Wong, M.H. 2016. Upgrading Food Wastes by Means of Bromelain and Papain to Enhance Growth and Immunity of Grass Carp (Ctenopharyngodon idella). Environmental Science and Pollution Research, 23(8): 7186-7194. doi: 10.1007/ s11356-015-4863-2.

Craig, S. \& Helfrich, L.A. 2002. Understanding Fish Nutrition, Feeds and Feeding. Cooperative Extension Service Publication. Virginia State University, USA.

Dabrowski, K. \& Glogowski, K. 1977. A study of application of proteolytic enzymes to fish food. Aquaculture, 12: 249-360. doi: 10.1016/0044-8486(77)90213-7

Effendie, M.I. 1997. Biologi Perikanan. Yayasan Pustaka Nusantara, Yogyakarta, $163 \mathrm{hlm}$.

Fenucci J.L., .1981. Studies on the nutrition of marine shrimp of the Penaeus. PhD Thesis, Faculty of Department of Biology,
University of Houston, Houston, Texas, USA, 185pp.

Hardiany, N.S. 2013. Enzim Pemecah Protein dalam Sel. Jurnal Kedokteran Indonesia, $1(1): 75-83$.

Hugues, de V., Komen, H., Quillet, E., Chatain, B., Allal, F., Benzie, J.A.H. \& Vandeputte, M. 2018. Improving feed efficiency in fish using selective breeding: a review. Aquaculture, 0(4): 833-851. doi: 10.1111/ raq. 12202.

Inaolaji, O.W. 2011. Growth Performance and Digestibility of Nile Tilapia, Oreochromis niloticus Fed Pineapple (Ananas comosus) Peel Meal-Based Diets. A Project Work Submitted to Department of Aquaculture and Fisheries Management. University of Agriculture Abeokuta. $45 \mathrm{p}$.

Khattak, F.M., Pasha, T.N., Hayat, Z. \& Mahmud, A. 2006. Enzymes in Poultry Nutrition. Journal of Animal and Plant Sciences, 16:1-2.

Lima, M.R.D., Ludke, M.D.C.M.M., Holanda, M.C.R.D., Pinto, B.W.C., Ludke, J.V. \& Santos, E.L. 2012. Performance and Digestibility of Nile tapia Fed with Pineapple Residu Bran. Maringa, 34(1):4147. doi: 10.4025/actascianimsci.v34i1.12 083

Manush, S.M., Srivastava, P.P., Kohli, M.P.S., Jain, K.K.; Ayyappan, S. \& Metar, S.Y. 2013. Combined Effect of Papain and Vitamin-C Levels on Growth Performance of Freshwater Giant Prawn, Macrobrachium rosenbergii. Turkish Journal of Fisheries and Aquatic Sciences, 13(4):79-48. doi: 10.4194/1303-2712-v13_ 3_10.

Masniar, M., Muchlisin, Z.A. \& S. Karina. 2016. Pengaruh Penambahan Ekstrak Batang Nanas pada Pakan terhadap Laju Pertumbuhan dan Daya Cerna Protein Pakan Ikan Betok (Anabas tetudineus). Jurnal Kelautan dan Perikanan Unsyiah, $1(1): 35-45$.

Mohan, R., Sivakumar, V., Rangasamy, T. \& Muralidharan, C. 2016. Optimization of Bromelain Enzyme Extraction from Pineapple (Ananas comosus), and Application in Process Industry. American Journal of Biochemistry and Biotechnology, 12(3):188-195. doi: 10.3844 /ajbbsp.2016.188.195. 
Nadzirah, K.Z., Zainal, S., Noriham, A. \& Normah. I. 2016. Application of Bromelain Powder Produced from Pineapple Crowns in Tenderising Beef Round Cuts. International Food Research Journal, 23(4):1590-1599.

NRC (National Research Council). 2011. Proteins and Amino Acids. Nutrient Requirements of Fish and Shrimp. National Academy Press, Washington, D.C., pp. 57-101.

Obirikorang, K.A., Amisaha, S., Fialor, S.C. \& Skov, P.V. 2015. Effects of Dietary Inclusions of Oilseed Meals on Physical Characteristics and Feed Intake of Diets for the Nile Tilapia, Oreochromis niloticus. Aquaculture Reports, 1:43-49. doi: 10.10 16/j.aqrep.2015.01.002.

Omotoyinbo, O.V., \& Sanni, D.M. 2017. Characterization of Bromelain from Part of Three Different Pineapple Varieties in Nigeria. American Journal of Bioscience, 5(3):35-41. doi: 10.11648/j.ajbio.20170503. 11.

Rachmania, R.A., Wahyudi, P., Wardani, A.M., \& Insani, D.R. 2017. Profil Berat Molekul Enzim Protease Buah Nanas (Ananas comosus L. Merr) dan Pepaya (Carica papaya L.) menggunakan Metode SDSPAGE. ALCHEMY Jurnal Penelitian Kimia, 13(1):52-65.

Rachmawati, D. \& Samidjan, I. 2018. Suplementasi Ekstrak Nanas Pada Pakan Terhadap Pemanfaatan Pakan Dan Pertumbuhan Udang Vaname (Litopenaeus Vannamei) Upaya Untuk Meningkatkan Produksi. Prosiding Seminar Nasional Kelautan dan Perikanan IV Tahun 2018;278-284.

Rachmawati, D., Samidjan, I. \& Maizirwan, M. 2017. Effect of phytase on growth performance, diet utilization efficiency and nutrient digestibility in fingerlings of Chanos chanos (Forsskal 1775). Philippine Journal of Science, 146(3):237-245.

Rachmawati, D. \& Samidjan, I. 2016. Effect of Phytase Enzyme on Growth Boost in the Artificial Feed Made of Plant Protein to Shorten Production Time of Giant Tiger Prawn [Penaeus monodon, (Fabricus 1798)]. Aquatic Procedia, 7:46-53. doi: 1016/j.aqpro.2016.07.006.

Subandiyono, S. Hastuti, \& R.A. Nugroho. 2018. Feed Utilization Efficiency and Growth of Java Barb (Puntius javanicus) Fed on Dietary Pineapple Extract. AACL Bioflux, $11(2): 309-318$

Steel, R.G.D., Torrie, J.H. \& Dickey, D.A. 1997. Principles and Procedures of Statistics: A Biometrical Approach. 3rd Edition, McGraw Hill, Inc. Book Co., New York, pp:352-358.

Syukri, M. \& Ilham, M. 2016. Pengaruh Salinitas Terhadap Sintasan Dan Pertumbuhan Larva Udang Windu (Penaeus monodon). Jurnal Galung Tropika, 5(2): 86-96.

Tricahyo, E. 1994. Biologi dan Kultur Udang Windu (Penaeus monodon FAB). Akademika Pressindo. Jakarta. $128 \mathrm{hlm}$.

Wilson, R.P. Energy relationships in catfish diets. 1982. In: Nutrition and Feeding of Channel Catfish. Stickney, R.R. \& R.T. Lovell (Ed.). Southern Cooperative Series, Auburn, Alabama, pp. 193-201.

Yuangsoi, B., Klahan, R., Charoenwattanasak, S. \& Lin, S.M. 2018. Effects of Supplementation of Pineapple Waste Extract in Diet of Nile Tilapia (Oreochromis niloticus) on Growth, Feed Utilization, and Nitrogen Excretion. Journal of Applied Aquaculture, 1(1):1-11. doi: 10.1080/1045 4438.2018.1439794 